\title{
Maksymalizacja korzyści ze współpracy organizacji pozarządowych z przedsiębiorstwami. Ujęcie metodyczne
}

\author{
Marek Ćwiklicki*
}

Streszczenie: Tło rozważań: Dla organizacji pozarządowych współpraca z biznesem jest tak samo istotna, jak realizacja wspólnych działań z administracją rządową. Kluczowa w świetle zasad współpracy jest znajomość podstaw metodycznych takiej współpracy.

Cele: W związku z powyższym celem artykułu jest opracowanie wskazówek postępowania pozwalających na zwiększanie wartości ze współpracy dla każdego partnera. Ponadto dokonano syntezy opisu korzyści i barier współpracy.

Metody: Do realizacji celu wykorzystano metodę analizy literatury przedmiotu oraz raportów diagnostycznych poświęconych badaniu stanu współpracy organizacji z biznesem w Polsce w latach 2011-2015. Umożliwiło to nie tylko przedstawienie kilku metodyk postępowania, ale także wskazanie metod pomocniczych.

Wyniki: W świetle literatury przedmiotu występuje dodatni bilans nakładów i efektów współpracy między organizacjami pozarządowymi a przedsiębiorstwami, jednak pod warunkiem poprawnej pod względem metodycznym realizacji partnerstwa. Wartość współpracy tworzy się już na etapie planowania.

Konkluzje: Nasuwa się wniosek o konieczności wdrożenia do organizacji pozarządowych zarządzania relacjami z biznesem.

Słowa kluczowe: współpraca, wartość, metodyka, organizacje pozarządowe, biznes.

\section{Wprowadzenie ${ }^{1}$}

Organizacje pozarządowe, aby móc realizować swoje cele podejmują współpracę instytucjonalną z różnymi podmiotami. W ostatnich latach dominowała tematyka ich współpracy z jednostkami samorządu terytorialnego w Polsce, między innymi dzięki wynikom projektu systemowego „Model współpracy administracji publicznej i organizacji pozarządowych - wypracowanie i upowszechnienie standardów współpracy" realizowanego w ramach Działania 5.4. PO KL. Tymczasem w opinii autora warto podjąć zagadnienie ko-

Publikacja została sfinansowana ze środków przyznanych Wydziałowi Zarządzania Uniwersytetu Ekonomicznego w Krakowie $w$ ramach dotacji na utrzymanie potencjału badawczego. operacji z sektorem biznesowym, które doczekało się w ostatnich latach raportów na swój temat [np. Centrum Rozwoju Społeczno-Gospodarczego, 2012; Karwacka, 2013; Nieporowski, 2015]. Ważność partnerów biznesowych uzasadnia porównywalna popularność w Polsce filantropii indywidualnej i instytucjonalnej oraz środków samorządowych w źródłach finansowania organizacji pozarządowych [Przewłocka, Adamiak, Herbst, 2013,

\footnotetext{
* Marek Ćwiklicki

Katedra Metod Organizacji i Zarządzania, Wydział Zarządzania

Uniwersytet Ekonomiczny w Krakowie

ul. Rakowicka 27, 31-510 Kraków

e-mail: marek.cwiklicki@uek.krakow.pl
} 
s. 117]. W szczególności podjęta problematyka jest wciąż aktualna dla podmiotów ekonomii społecznej. Analiza przeprowadzona prawie dekadę lat temu wykazała istnienie luk poznawczych dotyczących relacji polskiego sektora ekonomii społecznej z biznesem [Juraszek-Kopacz, 2006, s. 10].

Przedstawione powyżej uzasadnienie wyboru tematu należy uzupełnić o jeszcze jedno kluczowe zagadnienie, mianowicie o pytanie dotyczące tego, jak pozyskiwać i zwiększać korzyści ze współpracy zarówno dla organizacji pozarządowej, jak i biznesu. Wątek metodyczny w tym zakresie wydaje się być kluczowy, o czym świadczy jedna z zasad współpracy: wzajemne korzyści rozumiane jako „partnerstwo, którego zamierzeniem jest osiągnięcie wspólnych celów dających obu stronom satysfakcjonujące wyniki" [Rudnicka, Reichel, 2011, s. 7] lub „gdzie wyznaczony cel współpracy jest wspólny i równie istotny dla obu partnerów" [Kostulska, 2011, s. 17].

Celem niniejszego opracowania jest przedstawienie wytycznych metodycznych dla zwiększania wartości współpracy między organizacjami pozarządowymi a biznesem. Wspomniane wytyczne zostaną zidentyfikowane na podstawie studiów literatury przedmiotu dotyczącej tytułowej współpracy, a także analizy raportów krajowych i zagranicznych poświęconych temu zagadnieniu. Realizacja tak przyjętego celu zdecydowała o strukturze wewnętrznej artykułu. W pierwszej kolejności przedstawiono kluczowe elementy związane ze współpracą dwóch sektorów. Następnie omówiono bariery współpracy i problemy związane z maksymalizacją korzyści. W dalszej kolejności zawarto wskazówki opracowane na podstawie dostępnych badań, ułatwiające i zwiększające wartość współpracy.

\section{Przyczyny podejmowania współpracy NGO-biznes}

Organizacje pozarządowe są ze względu na swoją specyfikę niejako nastawione na współpracę. W przypadku biznesu, jak to wspomniano we wstępie niniejszego artykułu, może to mieć charakter relacji jednostronnej (filantropia instytucjonalna jako źródło finansowania działalności), ale bardziej istotne jest osiąganie wspólnych korzyści. Ich pojawienie się, udokumentowane w świetle zebranych raportów diagnostycznych, wzmacnia przekonanie o podjęciu działań partnerskich.

Analizy przeprowadzone w 2012 r. w ramach projektu „Promocja zaangażowania przedsiębiorstw w budowę kapitału społecznego w Polsce poprzez wykorzystanie narzędzi CSR" wykazały, że ponad 73\% badanych przedsiębiorstw współpracowała z organizacjami pozarządowymi. Jako główną przyczynę wskazano uzyskanie wsparcia u organizacji pozarządowych w realizacji celów biznesowych i społecznych przedsiębiorstw [Rokiczan, 2012]. Niewiele niższy wynik uzyskano także w innych badaniach przeprowadzonych w Polsce, gdzie deklarację współpracy z organizacjami pozarządowymi wyraziło $60 \%$ przedstawicieli firm [Centrum Rozwoju Społeczno-Gospodarczego, 2014, s. 51].

Badania wykazały, że przedstawiciele przedsiębiorstw jako główne przyczyny podjęcia współpracy z organizacjami pozarządowymi wskazali: wzmocnienie pozytywnego wizerunku firmy, wyspecjalizowane kompetencje pracowników NGO, uwiarygodnianie przez organizację pozarządową działań społecznych przedsiębiorstwa (budowanie społecznej wartości marki) [Karwacka, 2013, s. 16].

Istotniejsze z punktu widzenia podjętego tematu jest przekonanie, że podstawą współpracy biznesu z organizacjami pozarządowymi jest społeczna odpowiedzialność biznesu (Corporate Social Responsibility - CSR) [Ćwik, Januszewska, 2011, s. 14-15]. W takim ujęciu organizacje pozarządowe występują jako „jeden z interesariuszy firm", a partnerstwo jest „najbardziej dojrzałym podejściem do relacji z interesariuszami" [tamże, s. 17 i 22). W podobnym tonie Cohen [2013] przedstawia zna- 
Tabela 1. Najczęstsze formy współpracy krótko- i długoterminowej między NGO i biznesem

\begin{tabular}{|l|c|l|c|}
\hline \multicolumn{1}{|c|}{ Krótkoterminowe } & \% wskazań & \multicolumn{1}{c|}{ Długoterminowe } & $\%$ wskazań \\
\hline 1. Wsparcie rzeczowe & $72,3 \%$ & 1. Wsparcie finansowe & $63,0 \%$ \\
\hline 2. Wsparcie finansowe & $63,8 \%$ & 2. Konsultacje merytoryczne & $47,8 \%$ \\
\hline 3. Wolontariat pracowniczy & $36,2 \%$ & 3. Zaangażowanie w kampanie społeczne & $43,5 \%$ \\
\hline 4. Organizacja seminariów, konferencji & $29,8 \%$ & 4. Wolontariat pracowniczy & $39,1 \%$ \\
\hline 5. Konsultacje merytoryczne & $27,7 \%$ & 5. Wsparcie rzeczowe & $37,0 \%$ \\
\hline
\end{tabular}

Źródło: opracowano na podstawie [Karwacka, 2013, s. 20].

czenie działań CSR, argumentując, że wartość biznesowa przedsiębiorstw znacząco wzrasta po nawiązaniu współpracy z organizacjami pozarządowymi. Jako przykład podawana jest między innymi kooperacja Amerykańskiego Czerwonego Krzyża (ACK) z firmą kurierską FedEx. Otóż FedEx udostępnił swoją infrastrukturę logistyczną do transportu paczek ACK. Współpraca przyczyniła się do zwiększenia reputacji firmy i jej marki, co wpłynęło na wzrost przychodów, ale także na większe zadowolenie pracowników z powodu wspierania przez ich pracodawcę lokalnych społeczności, z których sami pochodzą [Cohen, 2013, s. 30]. Z powyższego wynika, że wyjście z inicjatywą partnerską ze strony biznesu jest uzasadnione ekonomicznie. Widząc obopólną korzyść współpracy podejmowane są inicjatywy przez sam biznes. Do jednej z nich można zaliczyć poradnik dedykowany kierującym NGO na temat tworzenia partnerstw wydany przez Hitachi Foundation [Watson, 2009].

Podobnie dla podmiotów ekonomii społecznej (PES) współpraca z biznesem jest postrzegana jako szansa na rozwój. Jako przykładowe obszary współpracy między PES a biznesem wymienia się: powiązania biznesowe, transfer know-how i społeczną odpowiedzialność biznesu [Kostulska, 2011, s. 20].

\section{Formy współpracy NGO-biznes}

W świetle badań współpraca między organizacjami pozarządowymi a biznesem przybiera kilka form, różniących się długo- ścią jej trwania. Na przykład można wyróżnić: filantropię korporacyjną, korporacyjne fundacje, licencjonowanie, sponsoring, promocje oparte na transakcjach (darowizna uzależniona od wyników sprzedaży firmy), wspólne przedsięwzięcia promocyjne i joint ventures [Wymer, Samu, 2003]. Inną propozycję klasyfikacyjną uwzględniono w badaniach krajowych, w których wymieniono: filantropię, sponsoring, udostępnianie usług, sprzętu i lokali, wolontariat pracowniczy, marketing zaangażowany społecznie, program społeczny, alians strategiczny [Rudnicka, Reichel, 2011, s. 11]. Najczęściej stosowane w Polsce formy współpracy przedstawiono w tabeli 1 z podziałem na horyzont czasowy.

Karwacka trafnie wyjaśnia, że „przy realizacji bardziej złożonych projektów przedsiębiorstwa preferują związanie się z organizacją pozarządową na dłuższy okres" [Karwacka, 2013, s. 21].

Powyżej przedstawione formy współpracy warto uzupełnić obszarami, w których biznes podejmuje kooperację z trzecim sektorem. Badania wykazały, że przedsiębiorcy najczęściej współpracują z organizacjami pozarządowymi w działaniach o następującej tematyce:

- rozwiązywanie problemów społecznych $(80,4 \%)$,

- promocja CSR $(68,6 \%)$,

- branżowe $(68,6 \%)$,

- edukacja $(66,7 \%)$,

- ochrona środowiska $(66,7 \%)$ [Karwacka, 2013, s. 11]. 


\section{Rysunek 1. Korzyści współpracy z organizacjami pozarządowymi dla krajowych przedsiębiorstw}

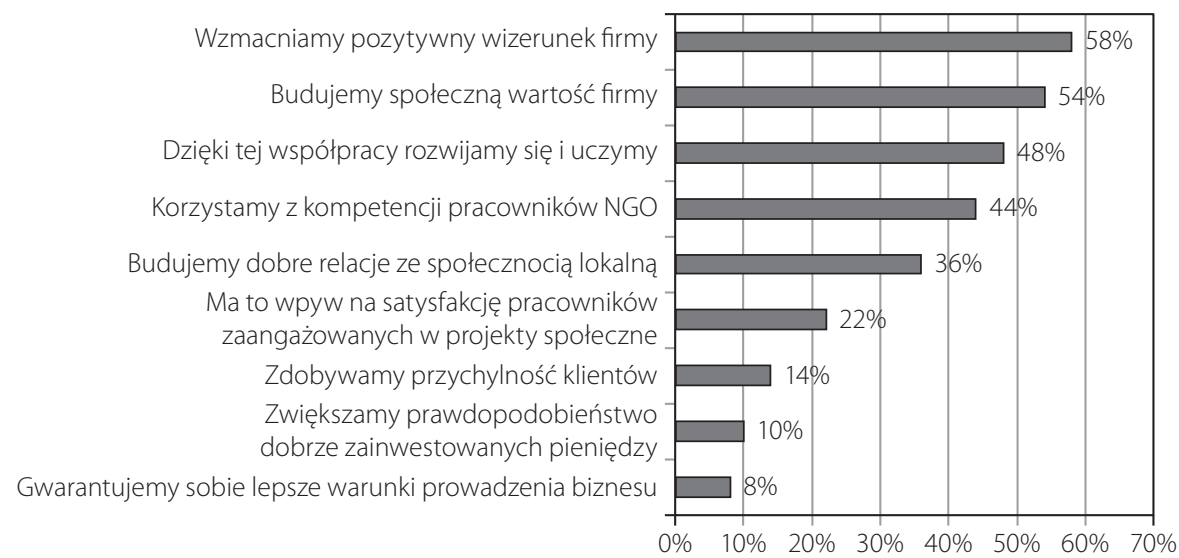

Źródło: opracowano na podstawie [Karwacka, 2013, s. 18]

W innych krajowych badaniach wyszczególniono trzy obszary angażowania się firm: edukacja, innowacje społeczne i nierówności społeczne [Nieporowski, 2015, s. 10].

Co ciekawe, zidentyfikowano zbieżność między decyzją o wyborze organizacji pozarządowej do współpracy a z rodzajami działań przedsiębiorstw [Karwacka, 2013, s. 11]. Analiza współpracujących podmiotów z firmami także wykazała, że z organizacjami pozarządowymi współpraca jest podejmowana częściej niż z innymi interesariuszami instytucjonalnymi [tamże].

\section{Korzyści współpracy}

W niniejszym punkcie zestawione zostaną korzyści współpracy między organizacjami pozarządowymi a przedsiębiorstwami z perspektywy każdej ze stron zidentyfikowane na podstawie krajowych raportów diagnostycznych.

Punkt widzenia przedsiębiorstw na temat korzyści wyraża rysunek 1 . Udzielone odpowiedzi są zbieżne z omówionymi powyżej przesłankami podjęcia współpracy przez biznes [Karwacka, 2013, s. 18].
Korzyści dla NGO określono między innymi w cytowanym poradniku Hitachi Foundation [Watson, 2009]. Zaliczono do nich:

- zwiększoną efektywność programu poprzez udział pracowników firmy nastawionych pro-zadaniowo,

- zwiększone znaczenie programu poprzez udzielenie porad dotyczących dopasowania podejmowanych działań do potrzeb beneficjentów organizacji pozarządowej,

- zwiększoną „dźwignię” polityczną, czyli wsparcie instytucjonalne przydatne we współpracy z władzami lokalnymi lub regionalnymi,

- zwiększoną rozpoznawalność i rozszerzoną reputację poprzez udział liderów biznesowych w przedsięwzięciach,

- wzmocnienie organizacyjnego potencjału poprzez przekazaną wiedzę i zasoby,

- rozszerzony strumień przychodów poprzez zlecanie zadań przez biznes [Watson, 2009, s. 3-4].

Natomiast zestawienie korzyści współpracy dla obydwóch stron przedstawiono w tabeli 2 . 
Tabela 2. Zestawienie korzyści współpracy NGO-biznes

\begin{tabular}{|l|l|}
\hline \multicolumn{1}{|c|}{ Korzyści dla organizacji pozarządowych } & \multicolumn{1}{|c|}{ Korzyści dla przedsiębiorstw } \\
\hline - wsparcie w realizacji misji organizacji - zwiększenie & - łatwiejszy dostęp do społeczności lokalnych (sektor NG0 cieszy \\
efektywności działania & się większym zaufaniem społecznym niż biznes) i innych \\
- dostęp do zasobów biznesu: finansowych, rzeczowych, & interesariuszy \\
ludzkich oraz do wiedzy i kompetencji & - dostęp do profesjonalnej wiedzy dotyczącej problemów \\
- zwiększenie profesjonalizmu funkcjonowania & społecznych, szzzególnie lokalnych, oraz sposobów ich \\
- poprawa jakości i efektywności działania & rozwiązywania \\
- dywersyfikacja źródeł finansowania & - możliwośćczerpania z doświadczenia organizacji w realizacji \\
- budowa pozycji na rynku & projektów społecznych i zarządzaniu nimi \\
& - budowanie wizerunku i reputacji \\
& - wykorzystanie doświadczenia organizacji pozarządowej \\
& dotyczącego współpracy z wolontariuszami do zaangażowania \\
& pracowników firmy w wrojekty społeczne (wolontariat \\
& pracowniczy) \\
& - komunikowanie wartości wewnątrz firmy \\
\hline
\end{tabular}

Źródło: opracowano na podstawie: [Ćwik, Januszewska, 2011, s. 11].

Powyższe zestawienia wykazują, że korzyści współpracy mają głównie charakter niematerialny. Próbując dokonać ich podsumowania można sformułować wniosek, iż w przypadku organizacji pozarządowych otrzymują one profesjonalne wsparcie, bardziej nastawione na efektywność i na wykonanie zadania. Natomiast przedsiębiorcy zyskują uspołecznienie swoich działań i społeczną wrażliwość charakterystyczną dla społecznej odpowiedzialności biznesu. Na tej podstawie można dojść do konkluzji, iż każdy z partnerów uzupełnia swoje słabe strony mocnymi danego partnera, a samo partnerstwo ma cechy symbiozy (mutualizmu).

Patrząc na korzyści z perspektywy wspólnego pożytku dla każdego z partnera można mówić o wartości wspólnej lub wartości współpracy. Taka wartość wynika z podstawowych cech samego partnerstwa. Na przykład J.M. Brinkerhoff [2002, s. 22] wyszczególnia wzajemność (w tym relacji) i tożsamość organizacyjną jako podstawy tworzenia wartości dodanej partnerstwa. Autorka dodaje, że w sytuacji uzyskiwania obopólnych korzyści z partnerstwa jest ono bardziej trwałe i sprawniej działające [ibidem].

\section{Bariery współpracy NGO-biznes}

Kwerenda opracowań na temat współpracy organizacji pozarządowych z biznesem doprowadziła do zebrania następujących danych na temat barier, trudności, przeszkód takiej kooperacji. Zbiorczo - zarówno z perspektyw organizacji pozarządowych jak i biznesu - przedstawione one zostały w tabeli 3.

Do przeszkód w podejmowaniu współpracy należy zaliczyć także ryzyka wynikające $z$ takiej kooperacji. Z badań wynika, że respondenci z firm postrzegają je jako: negatywny wpływ na wizerunek przedsiębiorstwa, nierozliczenie przekazanych środków, obarczenie większością działań projektowych, konieczność asekuracji potencjalnego niepowodzenia [Karwacka, 2013, s. 8].

Potencjalne ryzyka dla organizacji pozarządowych wynikające ze współpracy z biznesem to: zmarnowanie zasobów, zmniejszone dotacje, utrata organizacyjnej elastyczności, pogorszenie wizerunku z powodu współpracy z nieetycznym partnerem [Andreasen, 1996]. Osobne ryzyko pochodzi z nadmiaru sukcesu, na które organizacji nie jest przygotowana.

W poradniku na temat skutecznych partnerstw wydanym przez OECD w 2006 r. wska- 
Tabela 3. Trudności we współpracy organizacji pozarządowych z biznesem

\begin{tabular}{|l|l|}
\hline \multicolumn{2}{|c|}{ Trudności doświadczane przez: } \\
\hline \multicolumn{1}{|c|}{ organizacje pozarządowe } & \multicolumn{1}{c|}{ biznes } \\
\hline $\begin{array}{l}\text { - brak zaangażowania ze strony biznesu } \\
\text { - brak przygotowania kadrowego po stronie biznesu } \\
\text { - problemy z komunikacją i wzajemnym zrozumieniem } \\
\text { - nieterminowość } \\
\text { - brak zaufania } \\
\text { - niewywiązywanie się z obietnic danych organizacji (np. } \\
\text { wycofanie się firmy) }\end{array}$ & $\begin{array}{l}\text { - brak zrozumienia celów firmy przez organizacje } \\
\text { - nieodpowiednie przygotowanie organizacji do współpracy } \\
\text { - brak przygotowania kadrowego po stronie organizacji } \\
\text { - problemy z komunikacją i wzajemnym zrozumieniem } \\
\text { - brak informacji zwrotnych od organizacji } \\
\text { - nieterminowość organizacji }\end{array}$ \\
\hline
\end{tabular}

Źródło: opracowano na podstawie [Rokiczan, 2012, s. 16-17].

zano następujące przyczyny nieefektywnej współpracy:

- partnerzy nie wyrażają tych samych wartości ani zainteresowań.

- brak współdzielenia ryzyka, odpowiedzialności lub korzyści.

- nierówny udział w zasobach i wiedzy określających ich relatywny wpływ na podejmowanie decyzji w partnerstwie.

- jedna osoba lub partner ma pełnię władzy i/lub zarządzania przedsięwzięciem.

- istnieje ukryta motywacja, niezakomunikowana pozostałym partnerom.

- ustanowienie partnerstwa tylko dla zachowania pozorów.

- członkowie partnerstwa nie zostali przeszkoleni w identyfikacji spraw lub rozwiązywania wewnętrznych konfliktów.

- partnerzy nie zostali dobrani odpowiednio, w szczególności jeśli zerwanie partnerstwa jest trudne [Brandstetter i in., 2006, s. 11].

Krytyczne spojrzenie na współpracę z biznesem można też tłumaczyć potencjalną niestabilnością finansową cechującą sektor prywatny. W takim też kontekście można odczytać wyniki badań, które wykazały, że między rokiem 2009 a 2011 nastąpił w większy spadek korzystania filantropii indywidualnej i instytucjonalnej w porównaniu do środków samorządowych [Przewłocka i in., 2013, s. 117]. Jednak szersze spojrzenie na kondycję finansową trzeciego sektora prowadzi do oceny o pogorszeniu sytuacji również i jego w ostatnich latach [Kafel, 2014, s. 62].

\section{Przegląd sposobów zarządzania partnerstwem}

W literaturze przedmiotu można znaleźć kilka ujęć zarządzania partnerstwem wyrażonych w formie toku postępowania. Dostrzegając zróżnicowanie partnerstw w praktyce działalności organizacji pozarządowych i próbując dokonać syntetycznego opisu, D. Lewis stwierdza, że model partnerstwa nie może być po prostu replikowany z jednego przykładu do innego [Lewis, 2014, s. 219]. Autor postrzega partnerstwo jako działanie, w wyniku którego powstaje dopasowany do cech każdego partnera układ instytucjonalny i zadaniowy. Sam proces tworzenia partnerstwa składa się z następujących etapów:

1. Identyfikacja celów partnerstwa.

2. Zaprojektowanie mechanizmów stworzenia niezbędnych powiązań i kanałów komunikacyjnych.

3. Regularny przegląd celów i rozwoju partnerstwa [ibidem].

Powyższa metodyka jest bardzo ogólna i obejmuje głównie fazę planowania (etapy 1 i 2) i oceny partnerstwa (etap 3).

W poniżej przedstawionej propozycji metodycznej proces partnerstwa składa się z czterech etapów: 
Tabela 4. Zestawienie przykładowych narzędzi pomocniczych

\begin{tabular}{|l|l|}
\hline \multicolumn{1}{|c|}{ Nazwa narzędzia } & \multicolumn{1}{|c|}{ Opis } \\
\hline Formularz oceny partnera & $\begin{array}{l}\text { Lista pytań pozwalająca na wybranie partnera najbardziej dopasowanego pod } \\
\text { kątem celów. Powinna być wykorzystywana jako pomoc w dalszych rozmowach } \\
\text { z potencjalnymi partnerami }\end{array}$ \\
\hline Mapowanie interesariuszy & $\begin{array}{l}\text { Zbiór technik pozwalających na dokonanie klasyfikacji interesariuszy. } \\
\text { Technika 1: Forma tabelaryczna opisu interesariuszy według ustalonych kryteriów } \\
\text { (np. na co ma wpływ interesariusz, jakimi zasobami dysponuje itp.). } \\
\text { Technika 2: Metoda graficzna polegająca na rozmieszczeniu partnerów na } \\
\text { wykresie zgodnie z dwoma kryteriami: siły wpływu i poziomu zainteresowania } \\
\text { partnerstwem. } \\
\text { Technika 3: Przypisanie potencjalnych interesariuszy do ról jakie mogą pełnić } \\
\text { w partnerstwie (np. kontraktor, założyciel, dostarczyciel wiedzy, itd.) }\end{array}$ \\
\hline Przykładowa umowa partnerstwa & $\begin{array}{l}\text { Przykładowy formularz umowy składającej się z części: organizacje tworzące } \\
\text { partnerstwo, cele partnerstwa, rozwiązanie organizacyjne i procedury, zasoby }\end{array}$ \\
\hline Kwestionariusz ról partnerstwa i umiejętności & $\begin{array}{l}\text { Ocena ról i umiejętności według skali Likerta, wykorzystywana do określenia } \\
\text { mocnych stron każdego partnerstwa }\end{array}$ \\
\hline Wytyczne dla rozmowy partnerskiej & Porady dotyczące prowadzenia rozmowy \\
\hline Formularz przeglądu partnerstwa & $\begin{array}{l}\text { Służy do przeglądu stopnia osiągnięcia celów partnerstwa. Nie ma charakteru } \\
\text { formalnego }\end{array}$ \\
\hline Formularz studium przypadku & Struktura opisu zrealizowanego przedsięwzięcia w ramach partnerstwa \\
\hline Lista sprawdzająca dotycząca komunikacji & $\begin{array}{l}\text { Lista zawierająca wykaz potencjalnych odbiorców informacji, kanałów } \\
\text { komunikacyjnych i potencjalnego przesłania }\end{array}$ \\
\hline
\end{tabular}

Źródło: opracowano na podstawie [Tennyson, 2011].

1. Ustalenie zakresu i tworzenie partnerstwa.

2. Zarządzanie partnerstwem.

3. Przegląd i ocena funkcjonowania partnerstwa.

4. Utrzymywanie wyników [Tennyson, 2011, s. 6].

W tym ujęciu nawiązano do klasycznego cyklu działania zorganizowanego znanego pod akronimem PDCA (Plan-Do-Check-Act) [Ćwiklicki, Obora, 2011, s. 40]. Uwzględnienie w nim wszystkich faz świadczy o jego poprawności metodycznej. Należy dodać, że na potrzeby każdego etapu opracowano odpowiednie narzędzia pomocnicze, których krótki opis zawarto w tabeli 4.

Wyrazem określenia możliwości organizacji pozarządowej w tworzeniu partnerstwa jest identyfikacja swoich zasobów, ale także i pozostałych podmiotów, zwane także mapowaniem zasobów. Przykład takiej struktury przedstawiono w tabeli 5.
Inne ujęcie metodyczne, rozwijane od kilkunastu lat, bazuje na wartości współpracy. Maksymalizowanie korzyści, bądź jak to określa J.E. Austin i M.M. Seitanidi [2014, s. 4], tworzenie wartości współpracy (collaborative value), wymaga przede wszystkim zrozumienia źródeł ich powstawania. Można do tego celu posłużyć się pięcioelementowym modelem, którego schemat przedstawia rysunek $2^{2}$.

Rdzeniem spajającym pozostałe cztery części modelu jest zakres tworzenia wartości współpracy. Główną jego funkcją jest identyfikacja źródeł wartości i ich rodzajów. Określenie źródeł pozwala na opracowanie portfolio wartości i przypisanie ich partnerom. Na tej podstawie następuje ustalenie udziału członków w partnerstwie.

\footnotetext{
2 Omawiany model był już częściowo prezentowany na łamach „Ekonomii Społecznej” [por. Ćwiklicki, 2014]. Aby nie powtarzać opublikowanych już treści, model uzupełniono dodatkowymi opisami.
} 
Tabela 5. Schemat mapowania zasobów partnerstwa (fragment)

\begin{tabular}{|c|c|c|c|}
\hline Rodzaj zasobu & Sektor publiczny & Sektor biznesowy & Społeczeństwo \\
\hline Informacja (dostęp) & $\begin{array}{c}\text { Statystyki / Interpretacja } \\
\text { prawna }\end{array}$ & $\begin{array}{l}\text { Analiza rynku / } \\
\text { Analiza trendów }\end{array}$ & $\begin{array}{c}\text { Wiedza lokalna / } \\
\text { Społeczne uwarunkowania }\end{array}$ \\
\hline \multirow[t]{5}{*}{ Pomieszczenia } & \multicolumn{3}{|c|}{ Siedziba partnerstwa / Biuro projektowe } \\
\hline & \multicolumn{3}{|c|}{ Spotkania / Warsztaty } \\
\hline & \multicolumn{2}{|c|}{ Dedykowane wydarzenia } & - \\
\hline & \multicolumn{2}{|c|}{ Magazyn } & - \\
\hline & \multicolumn{3}{|c|}{ Punkt dostępu do informacji publicznej } \\
\hline \multirow[t]{2}{*}{$\begin{array}{l}\text { Produkty (w zależności } \\
\text { od charakteru projektu) }\end{array}$} & - & Lekarstwa, żywność, IT & - \\
\hline & \multicolumn{2}{|c|}{ Energia } & - \\
\hline \multirow[t]{3}{*}{ Inne } & \multicolumn{2}{|c|}{ Transport } & - \\
\hline & \multicolumn{2}{|c|}{ Sprzęt } & - \\
\hline & \multicolumn{2}{|c|}{ Meble } & - \\
\hline \multirow[t]{3}{*}{ Informacja (upowszechnienie) } & \multicolumn{3}{|c|}{ Elektroniczne systemy komunikacyjne } \\
\hline & \multicolumn{3}{|c|}{ Publikacja materiałów } \\
\hline & \multicolumn{3}{|c|}{ Sieci kontaktów } \\
\hline \multirow[t]{3}{*}{ Wiedza ekspercka } & \multicolumn{3}{|c|}{ Eksperci techniczni } \\
\hline & \multicolumn{3}{|c|}{ Szkolenia / rozwój kompetencji } \\
\hline & - & Zarządzanie & - \\
\hline \multirow[t]{5}{*}{ Relacje/kontakty } & - & \multicolumn{2}{|c|}{ Darczyńcy } \\
\hline & \multicolumn{2}{|c|}{ Decydenci } & \\
\hline & & \multicolumn{2}{|c|}{ Organizacje parasolowe } \\
\hline & \multicolumn{3}{|c|}{ Media } \\
\hline & Społeczeństwo & & Społeczeństwo \\
\hline \multirow[t]{5}{*}{ Personel } & \multicolumn{3}{|c|}{ Personel specjalistyczny } \\
\hline & \multicolumn{2}{|c|}{ Pracownicy czasowi } & - \\
\hline & - & \multicolumn{2}{|c|}{ Wolontariusze } \\
\hline & Studenci / Uczniowie & & \\
\hline & \multicolumn{3}{|c|}{ Wsparcie administracyjne } \\
\hline
\end{tabular}

Źródło: opracowano na podstawie: [Tennyson, 2011, s. 14].

Drugi element modelu - sposób myślenia o wartości współpracy - również ma charakter planistyczny. Jego funkcją jest zrozumienie postaw względem wartości, które zdaniem J.E. Austina i M.M. Seitanidi [2014, s. 42-43] można określić jako:

1. Wartość dla udziałowcy czy interesariuszy? - Tym pytaniem autorzy wyrażają dylemat w określaniu motywów podejmo- wania działań na rzecz społeczeństwa: czy jest to skoncentrowanie się na konkretnej grupie (udziałowcy), czy na innych grupach społecznych (interesariusze).

2. Empiryczna ocena społecznych i finansowych wyników. Zawiązywanie partnerstwa może być zdominowane przez myślenie w kategoriach efektywności ekonomicznej. Z tego względu pomiar oparty 


\section{Rysunek 2. Model tworzenia wartości współpracy}

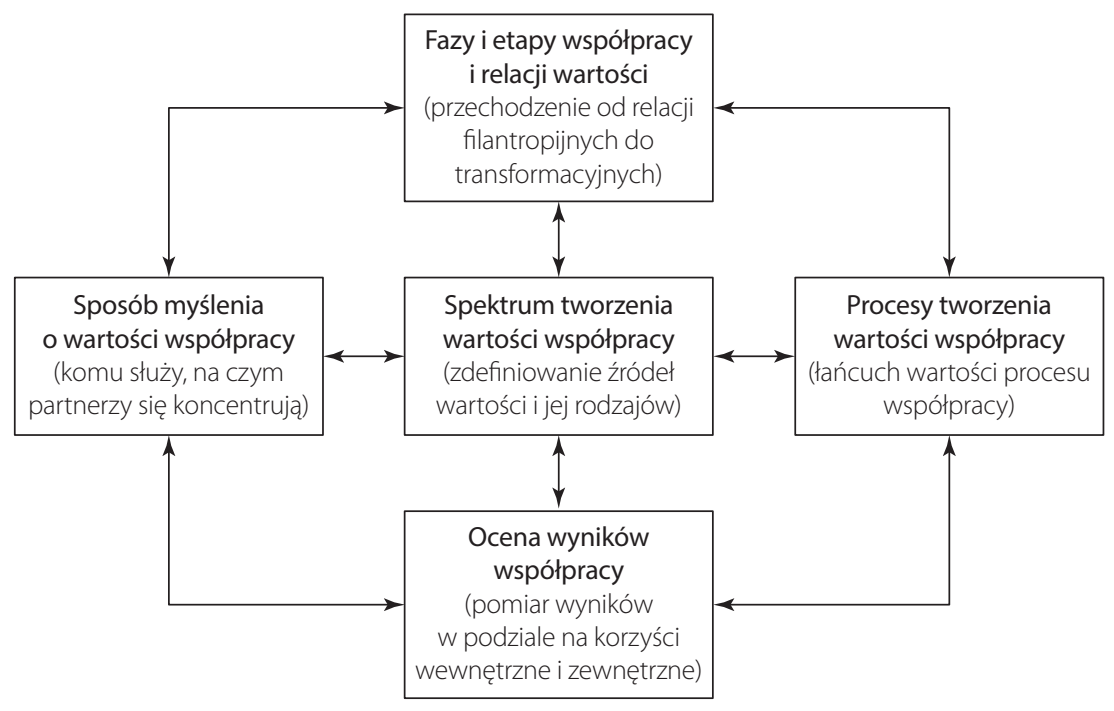

Źródło: opracowano na podstawie [Austin, Seitanidi, 2014, s. 177].

na danych finansowych jest łatwiejszy do przeprowadzenia w porównaniu do rejestracji efektów społecznych.

3. Wielokrotna motywacja - zgodnie z wynikami badań motywacja pochodząca z wartości organizacyjnych sprzyja zwiększaniu wartości ze współpracy bardziej niż traktowanie jej instrumentalnie.

4. Skoncentrowanie na integracji wartości - polega na patrzeniu na wartość z perspektywy ekonomicznej, środowiskowej i społecznej.

5. Skoncentrowanie na współpracy międzysektorowej - dotyczy współpracy na pograniczu działań "for profit" i „non profit”, co zwiększa wartość. Niniejszy wniosek Austin i Seitanidi formułują na podstawie analizy badań dotyczących kooperacji między trzecim sektorem a biznesem.

Kolejny element modelu dotyczy etapów partnerstwa. Warto poświęcić mu więcej miejsca, ponieważ jego ramy były prezentowane w literaturze przedmiotu jako tzw. ciągłość współpracy (Collaboration Continuum), opracowana konceptualnie przez J.E. Austina [2000]. Zgodnie z tym ujęciem lepsze efek- ty współpracy otrzymuje się poprzez przechodzenie ze współpracy o charakterze filantropijnym na transakcyjną, następnie integracyjną, aż w końcu transformacyjną. Przejścia mogą dokonać się w następujących wymiarach:

- dopasowania (zbieżność misji, znaczenie strategiczne, połączenie wartości, wiedza o problemie, ramy tworzenia wartości, skoncentrowanie na korzyściach),

- zaangażowanie (związki emocjonalne, koncentracja na interakcjach, zaangażowanie w działania, częstotliwość współpracy, zaufanie, aktywność, struktura, złożoność zarządzania),

- wspieranie (wielkość zasobów, rodzaj zasobów, związki między zasobami, synergia, uczenie się, innowacja, wewnętrzna zmiana, system wymiany informacji).

Warto zauważyć, że trzy elementy modelu scharakteryzowane powyżej mają charakter planistyczny. Wymiar funkcjonowania (działania) partnerstwa ujęty jest w kolejnym, czwartym elemencie. Konstytuują go procesy tworzenia wartości współpracy. Składają się na nie cztery główne fazy - każ- 
Tabela 5. Proces tworzenia wartości współpracy

\begin{tabular}{|l|}
\hline 1. Formowanie partnerstwa \\
\hline 1.1. Określenie problemu społecznego \\
1.2. Określenie intencji partnerów \\
1.3. Okré́lenie doświadczenia tworzenia wartości \\
1.4. Ocena zbieżności partnera \\
1.5. Opracowanie portfolio potencjalnej wartości współpracy \\
1.6. Określenie mistrzów partnerstwa \\
\hline 2. Selekcja \\
\hline 2.1. Mapowanie wspólnych interesów \\
2.2. Okré́lenie zasobów wartości \\
2.3. Rozpoznanie zdolności organizacyjnych \\
2.4. Rozwój kryteriów charakterystycznych dla partnerstwa \\
2.5. Ocena ryzyka \\
\hline 3. Wdrożenie \\
\hline 3.1. Eksperymentowanie \\
3.2. Adaptacja \\
3.3. Operacjonalizacja \\
3.4. Ocena \\
\hline 4. Instytucjonalizacja \\
\hline 4.1. Zakorzenienie współpracy (w organizacyjnych procedurach) \\
4.2. Konwergencja ram wartości \\
4.3. Wspólne zarządzanie \\
\hline
\end{tabular}

Źródło: opracowano na podstawie: [Austin, Seitanidi, 2014].

da złożona z kilku etapów. Ich zestawienie zawiera tabela 5 .

Wykonana sekwencja powyższych faz i etapów prowadzi do stworzenia wartości współpracy.

Piąty - i ostatni element modelu - dotyczy oceny wyników współpracy, która jest najsłabiej opisana pod względem metodycznym. Wynika to z trudności wiążących się z pomiarem niematerialnych korzyści. Dlatego też jako wskazówkę należy przyjąć uporządkowanie takiej oceny według analizy korzyści, jakie uzyskują poszczególni partnerzy i sposobu ich osiągnięcia.

Austin i Seitanidi [2014, s. 199-217] w uzupełnieniu do swojego modelu wymieniają kilkanaście punktów, na które należy zwrócić uwagę podczas planowania, realizacji i oceny partnerstwa. Dotyczy to: zrozumienia tworzenia wartości, osiągnię- cia sposobu myślenia o wartości współpracy, zaawansowania współpracy według jej etapów, zarządzania procesami tworzenia wartości, oceny rezultatów, poszukiwania odpowiednich partnerów, tworzenia więzi, zarządzania i organizacji, komunikacji, budowania zaufania, uczenia się, transformacji.

W poradniku dotyczącym budowania relacji korporacyjnych wskazano jako ich podstawę bardzo dobrą znajomość podejmowanych działań, która poprzez ich szczegółowy opis umożliwi identyfikację odpowiedniego rodzaju partnera [Alberta Government, 2014]. Do wspomnianych rodzajów zaliczono partnerstwa oparte na: sponsoringu, filantropii i znaczeniu społecznym projektu zbieżnym z priorytetami inwestycyjnymi partnera korporacyjnego [ibidem, s. 10]. 


\section{Podsumowanie}

Omówione w niniejszym artykule korzyści pozwalają na stwierdzenie o istnieniu dodatniego bilansu nakładów i efektów współpracy między organizacjami pozarządowymi a przedsiębiorstwami, jednak pod warunkiem poprawnej pod względem metodycznym realizacji partnerstwa.

Kluczowe dla podjętego tematu jest sformułowanie wskazówek zwiększających wartość z współpracy. W cytowanym już poradniku dla liderów NGO wydanym przez Hitachi Foundation zwiększenie prawdopodobieństwa sprawnego działania partnerstwa zależy od: 1) opisu celów partnerstwa, 2) mierzalnych celów i produktów partnerstwa, 3) wyraźnie określonych ról, odpowiedzialności i harmonogramu [Watson, 2009, s. 6].

\section{Literatura}

Alberta Government (2014). Building Corporate Relationships - A Toolkit for Nonprofits. Alberta, http:// culture.alberta.ca/community/resources-and-links/ tools/pdf/AlbertaCulture-Toolkit.pdf.

Andreasen A. R. (1996). „Profits for nonprofits: find a corporate partner", Harvard Business Review, 74(6), 47-50, 55-59.

Austin J. E. (2000). "Strategic Collaboration Between Nonprofits and Businesses", Nonprofit and Voluntary Sector Quarterly, 29(1), 69-97, http://doi. org/10.1177/089976400773746346

Austin, J.E., Seitanidi, M.M. (2014). Creating value in nonprofit-business collaborations: new thinking and practice (First edition). San Francisco, CA: Jossey-Bass, a Wiley Brand.

Brandstetter R., de Bruijn J., Byrne M., Deslauriers H., Förschner M., Machačová J., Scoppetta A. (2006). Successful partnerships. A guide. Wiedeń: OECD LEED, http://www.oecd.org/cfe/leed/36279186.pdf.

Brinkerhoff J. M. (2002). "Government-nonprofit partnership: a defining framework", Public Administration and Development, 22(1), 19-30, http://doi. org/10.1002/pad.203.

Centrum Rozwoju Społeczno-Gospodarczego (2012). Współpraca biznes - NGO: stan wiedzy, dotychczasowe doświadczenia, postawy i oczekiwania. Raport końcowy z pierwszego etapu badania. Szczecin, http://www.odpowiedzialnafirma.pl/Web/upload/
Podsumowując przedstawione powyżej trzy metodyki funkcjonowania partnerstwa NGO-biznes można zauważyć zbieżność w identyfikacji głównych etapów zgodnie z cyklem działania zorganizowanego. Wniosek sformułowany na tej podstawie dotyczy faktu, iż wartość współpracy tworzy się już na etapie planowania. Myślenie o niej po formalnym zawiązaniu partnerstwa nie da takich efektów, jak uwzględnienie tego w fazie preparacyjnej. Nie bez kozery wskazówki zawarte w poprzednim akapicie dotyczą właśnie planowania.

Próbując sformułować nowe kierunki badań w tytułowym obszarze, nasuwa się wniosek o konieczności wdrożenia do organizacji pozarządowych zarządzania relacjami z biznesem. Ten wątek wpisuje się w zagadnienie public relations i zarządzanie relacjami z klientami (ang. Customer Relationship Management).

Raport\%20nt.\%20wsp\%C3\%B3\%C5\%82pracy\%20 NGO\%20i\%20biznesu.pdf.

Centrum Rozwoju Społeczno-Gospodarczego (2014). Współpraca biznes-NGO: Ocena zmiany jakości współpracy biznesu i III-go sektora. Raport końcowy z badania. Szczecin, http://www.odpowiedzialnafirma.pl/Web/upload//Ocena\%20zmiany\%20 jako\%C5\%9Bci\%20wsp\%C3\%B3\%C5\%82pracy\%20 biznesu\%20i\%20NGO.pdf.

Cohen T. (2013). „Business Value Boosted When Tied To Nonprofit", The NonProfit Times, 1 April, http:// www.thenonprofittimes.com/wp-content/uploads/2013/04/4-1-13_SpecialReport_CSR.pdf.

Ćwiklicki M. (2014). „Recenzja książki pt. Creating Value in Nonprofit-Business Collaborations. New Thinking and Practice (autorzy: James E. Austin i M. May Seitanidi)", Ekonomia Społeczna, (2), 71-74.

Ćwiklicki M., Obora H. (2011). Wprowadzenie do metod TQM. Kraków: Wydawnictwo Uniwersytetu Ekonomicznego.

Ćwik N., Januszewska J. (2011). Współpraca organizacji pozarządowych z biznesem. Poradnik efektywnej współpracy. Forum Odpowiedzialnego Biznesu, https://odpowiedzialnybiznes.pl/wp-content/uploads/2014/04/Biznes-NGO_FOB.pdf.

Juraszek-Kopacz B. (2006). "Ekonomia społeczna a biznes - współistnienie, konkurencja, współpraca", Ekonomia Społeczna Teksty, http://portal.ngo.pl/files/ kuj-pom.ngo.pl/public/SES/biblioteka/autorskieJuraszekESabiznes.pdf. 
Kafel T. (2014). Metody profesjonalizacji organizacji pozarządowych. Kraków: Wydawnictwo Uniwersytetu Ekonomicznego w Krakowie.

Karwacka M. (2013). Postrzeganie współpracy z organizacjami pozarzadowymi przez przedsiębiorstwa społecznie odpowiedzialne. Raport z badania. Toruń: CRNavigator, http://www.crnavigator.com/materialy/ bazadok/339.pdf.

Kostulska M. (2011). „Możliwości współpracy organizacji pozarządowych z biznesem oraz korzyści z takiej współpracy", w: Jak oczarować biznes? Poradnik dla organizacji pozarzqdowych. Fundacja Tallo, http://scop. sopot.pl/_pliki/Poradnik_Jak_oczarowac_biznes.pdf.

Lewis D. (2014). Non-governmental organizations, management and development (Third edition). Abingdon, Oxon; New York, NY: Routledge.

Nieporowski P. (2015). Raport statystyczny z badania realizowanego w ramach projektu Wsparcie dla współpracy partnerskiej - wiedza, narzędzia, praktyka. ZieIona Góra: Fundacja CSR Profit, http://csrprofit.com/ files/page/c94c109285ce/file/FIO_Raport\%20z\%20 konsultacji\%20spolecznych.pdf.

Przewłocka J., Adamiak P., Herbst J. (2013). Podstawowe fakty o organizacjach pozarząowych. Raport z badania 2012. Warszawa: Stowarzyszenie Klon/Jawor, http://www.ngo.pl/PodstawoweFakty_2012_ra-
port/ebook/content/PodstawoweFaktyNGO_2012_ KlonJawor_raport.pdf.

Rokiczan M. (2012). Współpraca Biznes-NGO: stan wiedzy, dotychczasowe doświadczenia, postawy i oczekiwania. Centrum Rozwoju Społeczno-Gospodarczego, http://www.ekonomiaspoleczna.pl/files/ ekonomiaspoleczna.pl/public/OSESVI_prezentacje/ rokiczan_prezentacja_oses.pdf.

Rudnicka A., Reichel J. (2011). Jak przygotować program współpracy organizacji pozarządowej z przedsiębiorstwami? Łódź: Centrum Strategii i Rozwoju Impac, http://dspace.uni.lodz.pl:8080/xmlui/bitstream/ handle/11089/8735/CSRImpact-978-83-932160-1-7. pdf?sequence $=1$.

Tennyson R. (2011). The Partnering toolbook. An essential guide to cross-sector partnering. Oxford: The Partnering Initiative, http://thepartneringinitiative. org/wp-content/uploads/2014/08/Partnering-Toolbook-en-20113.pdf.

Watson O. (2009). A Pocket Guide for Nonprofit Leaders. Washington: The Hitachi Foundation, http:// www.hitachifoundation.org/storage/documents/pocket_guide_nonprofit.pdf.

Wymer W.W., Samu S. (2003). „Dimensions of Business and Nonprofit Collaborative Relationships", Journal of Nonprofit \& Public Sector Marketing, 11(1), 3-22, http://doi.org/10.1300/J054v11n01_02.

\section{Value Maximisation in Non-Government Organisations and Enterprises Cooperation. Methodological Aspects}

Summary: Background: Cooperation between NGO and business is as important issue the same as realisation of joint activities with government. In the light of cooperation principles a basic knowledge of the methodology of such cooperation is a key to success.

Objective: Therefore the objective of this article is to provide guidelines of conduct to increasing the value of collaboration for each partner. In addition to it, a synthetic description of the benefits and barriers to cooperation was prepared.

Research methods: The critical analysis of literature and diagnostic reports devoted to the study of the state of NGO-business cooperation in Poland in 2011-2015 was employed. It allowed not only to indicate and discuss a couple of methodologies, but also to describe auxiliary methods.

Results: In the light of the literature review there is a positive balance of costs and benefits of cooperation between NGOs and business, however, realised correctly in terms of methodology. The value of cooperation is created in the planning stage.

Conclusions: The conclusion is the need to implement business relationship management into non-governmental organizations.

Keywords: cooperation, value, methodology, non-government organizations, business.

\section{Prawa autorskie i licencja / Copyright and License}

Artykuł opublikowano na licencji Creative Commons

Uznanie autorstwa - Użycie niekomercyjne - Bez utworów zależnych 3.0 Polska http://creativecommons.org/licenses/by-nc-nd/3.0/pl/

This article is published under the terms of the Creative Commons Attribution - NonCommercial - NoDerivs (CC BY-NC-ND 3.0) License

http://creativecommons.org/licenses/by-nc-nd/3.0/ 